\title{
Validation of a liquid chromatographic method for determination of related substances in a candidate certified reference material of captopril
}

\author{
Raquel Nogueira ${ }^{*}$, Wagner Wollinger ${ }^{1}$, Thaís Elias da Silva ${ }^{1}$, Leonardo Mesquita de Oliveira ${ }^{1}$, \\ Eliane Cristina Pires do Rego ${ }^{1}$, Gabriela Fernandes Moreira ${ }^{2}$, Juliano Smanioto Barin ${ }^{1}$, Luciane \\ Varini Laporta ${ }^{1}$, Márcia Foster Mesko ${ }^{1}$, Celso Figueiredo Bittencourt ${ }^{1}$, Janaína Marques \\ Rodrigues $^{1}$, Valnei Smarçaro da Cunha ${ }^{1}$
}

${ }^{1}$ Brazilian National Institute of Metrology, Standardization and Industrial Quality (Inmetro), Chemical Metrology Division (Dquim), Organic Analysis Laboratory (Labor), ${ }^{2}$ Brazilian National Institute of Metrology, Standardization and Industrial Quality (Inmetro), Materials Metrology Division (Dimat)

\begin{abstract}
This paper describes the validation of a reversed-phase high performance liquid chromatography method (RP-HPLC) with diode array detection (DAD) for determination of related substances (impurities from organic synthesis and degradation products) of captopril according to the Brazilian Pharmacopeia IV. The aim of this study was to guarantee the method accuracy for quantification of related substances, an essential requisite to determine, using the mass balance approach, the captopril content in the first Brazilian certified reference material (CRM) of an active pharmaceutical ingredient (API), developed by Inmetro. The captopril instability in solution is discussed and the captopril content determined by mass balance is compared to the results from titration and differential scanning calorimetry (DSC).
\end{abstract}

Uniterms: Captopril/qualitative analysis. Medicines/analysis/method validation. Medicines/analytical quality control. High performance liquid chromatography/qualitative analysis. Medicines/contamination. Captopril/certified reference standards.

\begin{abstract}
Este artigo descreve a validação de método de cromatografia líquida de alta eficiência em fase reversa (CLAE-RP) com detector de fotodiodos (DAD) para determinação de substâncias relacionadas (impurezas orgânicas de síntese e produtos de degradação) de captopril segundo Farmacopéia Brasileira IV ed. Este estudo teve como objetivo garantir que o método é capaz de quantificar com exatidão o teor de substâncias relacionadas, um requisito essencial para que o teor de captopril seja determinado por balanço de massa no primeiro material de referência certificado (MRC) de fármacos brasileiro, o qual foi desenvolvido pelo Inmetro. A instabilidade do captopril em solução é discutida em detalhes e o teor de captopril determinado por balanço de massa é comparado com aqueles obtidos por titulação e por calorimetria exploratória diferencial (DSC).
\end{abstract}

Unitermos: Captopril/análise qualitativa. Medicamentos/análise/validação de método. Medicamentos/ controle analítico de qualidade. Cromatografia líquida de alta eficiência/análise qualitativa. Medicamentos/ contaminação. Captopril/padrões de referência.

\section{INTRODUCTION}

The Brazilian National Institute of Metrology, Standardization and Industrial Quality (Inmetro) has recently

\footnotetext{
*Correspondence: R. Nogueira. Instituto Nacional de Metrologia, Normalização e Qualidade Industrial (Inmetro), Divisão de Metrologia Química, Laboratório de Análise Orgânica. Av. Nossa Senhora das Graças, 50 - Xerém, 25250-020 - Duque de Caxias - RJ, Brazil. E-mail: rnogueira@inmetro.gov.br
}

started a project to develop certified reference materials (CRMs) of active pharmaceutical ingredients (APIs). In 2010, the captopril CRM, which is the first Brazilian certified reference material of API, was presented by this institute. Captopril is an angiotensin I converting enzyme inhibitor widely used in the treatment of hypertension and congestive heart failure (Stultzer at al., 2009).

CRMs are defined as stable and homogeneous mate- 
rials, which are accompanied by a certificate declaring the value of a specified property (the API content in the scope of this paper) and the associated measurement uncertainty, in order to guarantee metrological traceability (ISO Guide 35:2006; JCGM, 2008). This traceability, which is a requirement of the ISO 17025:2005 standard and corresponds to "an unbroken chain of comparisons to national or international standards, all having stated uncertainties" (Duewer et al., 2004), cannot be ensured through the use of "non-certified" reference materials (also called reference standards).

The availability of certified reference materials for pharmaceutical use remains limited. The United States Pharmacopeia (USP), for instance, whose reference standards have been available since 1926 (Williams et al., 2006), developed its first CRM only in September 2008: dextromethorphan hydrobromide, which was followed in 2009 by theophylline, phenytoin and carbamazepine CRMs (The United States Pharm. Convention, 2010). We expect that in the near future the demand for pharmaceutical CRMs may be increasingly met by Pharmacopeias or National Metrology Institutes (NMIs).

The requirements for preparation of CRMs are described by the ISO Guides 34:2009 and 35:2006, and include material characterization, homogeneity evaluation, short- and long-term stability studies, as well as measurement uncertainty estimation.

The characterization step includes the determination of the property value, which in our case was the captopril content in the CRM and was determined by mass balance according to eq. 1 .

Captopril $(\%)=100 \%-\Sigma$ organic impurities $(\%)-$ $\Sigma$ inorganic impurities (\%) $-\Sigma$ volatiles (water and solvents) (\%) (eq. 1)

The mass balance approach allows determination of API content with standard deviations up to 10 times lower than those obtained by traditional assay methods (Hofer, Olsen, Rickard, 2007). The precision of the HPLC assays, for instance, is estimated to be in the range of $0.5-1.0 \%$ (Gorog, 2005). More precise results (smaller standard deviations) have the advantage of consequently lower associated measurement uncertainties. This justifies the increasing importance of tests for determination of impurities compared to those for assay of analytes (Gorog, 2005).

In order to use the mass balance equation, it is necessary to accurately quantify all impurities, including those from organic synthesis and degradation products. The organic impurities content in the captopril candidate certified reference material was determined by RP-HPLC-
DAD, according to the related substances test method given in the Brazilian Pharmacopeia IV monograph in question. This method has been validated, as described in this article, in order to guarantee that it is adequate for the intended use (ICH, 1994; Anvisa, 2003; ISO 17025:2005) and to prove its capacity to generate accurate results that could be used for the mass balance calculation.

\section{MATERIALS AND METHODS}

\section{Instrumentation}

For determination of related substances, a high performance liquid chromatographic (HPLC) Shimadzu system equipped with a quaternary pump LC-20AT, on-line degasser DGU-20A 3 /DGU-20A , auto-sampler SIL-20A/20AC, photodiode array detector SPD-20A and interface CBM$20 \mathrm{~A} / 20 \mathrm{~A}$, was used. The data were processed using the software Lab Solution. The system suitability test (5 replicate injections, allowed relative standard deviation for peak areas $\leq 2 \%$ ) (USP 32 ) was carried out before each set of validation experiments using a $10 \mu \mathrm{g} / \mathrm{g}$ captopril solution, in order to confirm the HPLC system performance.

The differential scanning calorimetry measurements were performed using a DSC Q1000 (TA Instruments) according to Moreira et al. (2010). For gravimetric preparation of samples, an analytical balance AUW 220D (Shimadzu) with $0.01 \mathrm{mg}$ resolution was used.

\section{Samples and reagents}

The studies were performed using samples of the first Inmetro batch of captopril CRM, whose certified reference value and expanded uncertainty $(U)$, using the value of 2 as coverage factor for a confidence level of approximately $95 \%$ (ABNT / Inmetro, 2003), was 99.565 $0.093 \% \mathrm{w} / \mathrm{w}$ (Nogueira et al., in press).

The captopril USP reference standard (batch $\mathrm{H}$ $09120 \mathrm{H}, 100.0 \%$ ) and the captopril disulfide USP reference standard (batch H0F251, 99.0\%) were not dried before use.

The reagents used for sample preparation and chromatographic analysis were methanol HPLC grade (Tedia Brazil), $o$-phosphoric acid $85 \% \mathrm{w} / \mathrm{w}$ for analysis (Tedia Brazil), hydrochloric acid p.a. (Merck), sodium hydroxide p.a. (Merck), hydrogen peroxide $30 \%$ p.a. (Merck) and water type I.

\section{Method description}

The HPLC method was based on the related substances test of captopril described in the corresponding 
Brazilian Pharmacopeia IV monograph. The analysis conditions were: mobile phase, methanol - phosphoric acid $0.11 \%(55: 45, \mathrm{v} / \mathrm{v})$; flow-rate, $1 \mathrm{ml} / \mathrm{min}$; UV detection, $220 \mathrm{~nm}$; injection volume, $20 \mu \mathrm{l}$. The HPLC column was RP18, $25 \mathrm{~cm} \times 4.6 \mathrm{~mm}$ i.d., $5 \mu \mathrm{m}$, Supelcosil (Supelco), to which a pre-column RP18, $4.6 \mathrm{~mm}$ i.d., $5 \mu \mathrm{m}$ (Varian) was attached.

\section{Method validation}

All solutions for validation studies were prepared gravimetrically, using mobile phase as the diluent.

The method specificity was evaluated by means of analysis of diluent (mobile phase), captopril disulfide USP reference standard (10 $\mu \mathrm{g} / \mathrm{g}$ solution), captopril USP reference standard (500 and $10 \mu \mathrm{g} / \mathrm{g}$ solutions), captopril CRM samples (500 and $10 \mu \mathrm{g} / \mathrm{g}$ solutions), mixtures of captopril disulfide USP reference standard and captopril CRM (solutions containing 10 and $500 \mu \mathrm{g} / \mathrm{g}$, respectively) and mixtures of captopril disulfide and captopril USP reference standards (solutions containing 10 and $500 \mu \mathrm{g} / \mathrm{g}$, respectively). Additionally, samples of captopril CRM exposed to temperatures of $80{ }^{\circ} \mathrm{C}, 120^{\circ} \mathrm{C}, 140^{\circ} \mathrm{C}$ and $250^{\circ} \mathrm{C}$ or treated with $1 \mathrm{~mol} / \mathrm{L} \mathrm{HCl}, 1 \mathrm{~mol} / \mathrm{L} \mathrm{NaOH}$ or $3 \%$ $\mathrm{H}_{2} \mathrm{O}_{2}$ for $5 \mathrm{~h}$ were analyzed. After treatment, the samples were neutralized (in case of acidic or basic conditions) and then diluted with mobile phase to reach the analysis concentrations (500 and $10 \mu \mathrm{g} / \mathrm{g}$ solutions).

In order to evaluate the captopril stability in the diluent (mobile phase), $500 \mu \mathrm{g} / \mathrm{g}$ solutions of captopril CRM (prepared in triplicate from flasks 16, 180 and 446) were transferred to HPLC vials and kept at $15{ }^{\circ} \mathrm{C}$ in the autosampler. The first injection of all solutions was performed in a random fashion, being followed by injections 2 and 3 performed in the same manner. The test was repeated using freshly prepared CRM solutions.

The linearity test was carried out using 11 individual solutions of captopril and captopril disulfide USP reference standards in the concentration range of 0.01 to $500 \mu \mathrm{g} / \mathrm{g}$. The captopril solutions were prepared both from the same stock solution and from different stock solutions freshly made before injection. For captopril disulfide, the dilutions were prepared from the same stock solution.

The limit of detection (LOD) and the limit of quantitation (LOQ) were initially estimated from the linearity data. For captopril disulfide, the results were then confirmed by preparing a dilution series ( 9 solutions) in the concentration range of $0.01 \mu \mathrm{g} / \mathrm{g}$ to $1.00 \mu \mathrm{g} / \mathrm{g}$, which was sufficient to obtain responses (peak heights) equivalent to around 10 times the noise (estimated from baseline) (LOQ) or to around 3 times the noise (LOD), as required by the signal-to-noise (S/N) ratio method ( $\mathrm{ICH}, 1994)$.

The repeatability was evaluated by six repeated injections of captopril and captopril disulfide USP reference standards (10 $\mu \mathrm{g} / \mathrm{g}$ individual solutions). This test was repeated on a different day by a different analyst in order to verify intermediate precision.

The recovery tests for accuracy evaluation were performed using solutions of captopril disulfide USP reference standard at the concentrations of 7.5, 10.0 and $12.5 \mu \mathrm{g} / \mathrm{g}(75 \%$ to $125 \%$ of the total organic impurity limit of $10 \mu \mathrm{g} / \mathrm{g}$ ), with or without the addition of $500 \mu \mathrm{g} / \mathrm{g}$ of captopril CRM or captopril USP reference standard (considered as matrixes). These two matrixes were also individually analyzed to determine their original captopril disulfide content.

For comparison of different methods, the mass balance calculation of the captopril content was done using eq. 1 . The content of organic impurities in the captopril CRM was determined by RP-HPLC-DAD, the inorganic impurities were estimated by residue of ignition (sulphated ash) using 9 captopril CRM samples of $1 \mathrm{~g}$ each, ignited at $600{ }^{\circ} \mathrm{C}$ until constant weight after addition of sulfuric acid, while the volatiles were determined by loss on drying at $60{ }^{\circ} \mathrm{C}$ under vacuum for 3 hours using 10 captopril CRM samples of $0.5 \mathrm{~g}$ each.

The robustness test was done by HPLC analysis of diluent (mobile phase), captopril CRM solution $(10 \mu \mathrm{g} / \mathrm{g})$ and captopril USP reference standard solution $(10 \mu \mathrm{g} / \mathrm{g})$ analyzed under eight different experimental conditions, which will be described in the corresponding section.

\section{RESULTS AND DISCUSSION}

The following parameters were evaluated for the method validation:

1. Specificity;

2. Stability of solutions;

3. Linearity and working range;

4. Limit of detection (LOD) and limit of quantitation (LOQ);

5. Repeatability and intermediate precision;

6. Accuracy;

7. Robustness.

\section{Specificity}

According to resolution RE-899 of the Brazilian National Health Surveillance Agency (Anvisa, 2003), specificity is the capacity of the method to measure exactly the compound of interest, even in the presence of impurities, degradation products and matrix components. 
Figures 1 and 2 show the chromatograms for captopril disulfide and captopril USP reference standards, respectively, while Figure 3 shows the chromatogram for the captopril CRM. Captopril eluted at the retention time $\mathrm{t}_{\mathrm{R}}=4.3 \mathrm{~min}$, while its main impurity captopril disulfide eluted at the retention time $t_{R}=6.7 \mathrm{~min}$. Captopril disulfide was present as an impurity both in the captopril USP reference standard (content around $0.07 \%$ ) (Figure 2) and in the captopril CRM (Figure 3). For captopril CRM samples,

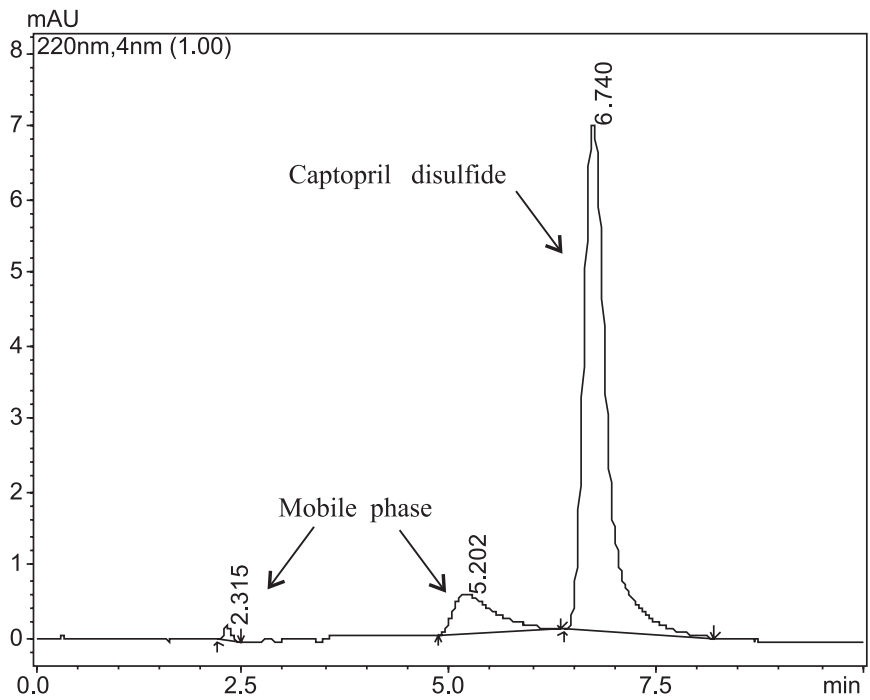

FIGURE 1 - Chromatogram of captopril disulfide USP reference standard $(10 \mu \mathrm{g} / \mathrm{g})$, showing captopril disulfide peak $\left(\mathrm{t}_{\mathrm{R}}=6.7 \mathrm{~min}\right)$ and mobile phase signals. Experimental conditions: HPLC column, RP18 $25 \mathrm{~cm}$ x $4.6 \mathrm{~mm}$ i.d. $5 \mu \mathrm{m}$; mobile phase, methanol - phosphoric acid $0.11 \%(55: 45, \mathrm{v} / \mathrm{v})$; flow-rate, $1 \mathrm{~mL} / \mathrm{min}$; UV detection, $220 \mathrm{~nm}$; injection volume, $20 \mu \mathrm{L}$.

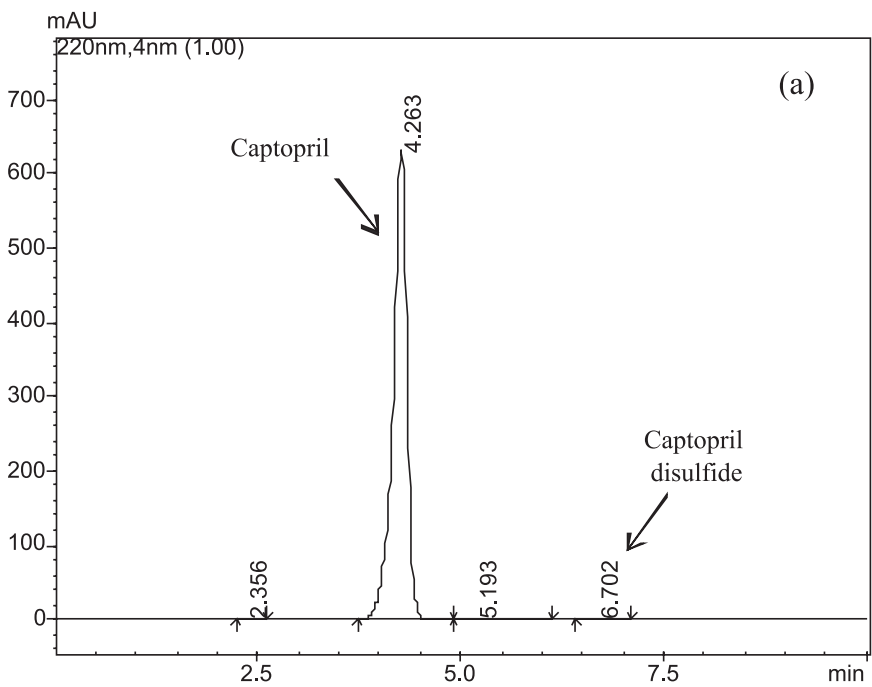

the chromatograms showed, besides the peaks of captopril and captopril disulfide, three peaks of unknown impurities $\left(t_{R}=3.5 \mathrm{~min}, t_{R}=3.7 \mathrm{~min}\right.$ and $\left.t_{R}=6.0 \mathrm{~min}\right)($ Figure 3$)$.

The diluent (mobile phase) was responsible for two signals observed in the chromatograms, whose areas remained constant during the validation and RM certification experiments, and which were sufficiently resolved from the peaks of captopril and captopril disulfide (Figures 1 to 3 ). There was no indication that these signals could overlap with an impurity peak based on the specificity test results: no increase in the areas of these diluent peaks was observed in the chromatograms of samples exposed to intense stress conditions $\left(80^{\circ} \mathrm{C}, 120^{\circ} \mathrm{C}, 140{ }^{\circ} \mathrm{C}, 250{ }^{\circ} \mathrm{C}, 1 \mathrm{~mol} / \mathrm{L}\right.$ $\mathrm{HCl}, 1 \mathrm{~mol} / \mathrm{L} \mathrm{NaOH}$ and $3 \% \mathrm{H}_{2} \mathrm{O}_{2}$ ).

The results for the specificity test are summarized in Table I. The peaks of captopril and captopril disulfide were sufficiently resolved $\left(\mathrm{R}_{\mathrm{s}} 5.0\right)$, in accordance with the Brazilian Pharmacopeia IV acceptance criteria $\left(\mathrm{R}_{\mathrm{s}} \mathrm{min}\right.$ 2.0). For the peaks of captopril and captopril disulfide, peak purity indexes of at least 0.98 were obtained, even after exposure of samples to temperatures up to $140{ }^{\circ} \mathrm{C}$ or to other stress conditions (acidic, basic or oxidizing). The disulfide captopril could be sufficiently recovered in the presence of matrixes (captopril USP reference standard or captopril CRM) (at least $96.8 \%$ ). Therefore, the method validation regarding specificity has been demonstrated.

\section{Stability of solutions}

Of the nine captopril impurities described in the literature (LGC, 2010), captopril disulfide was the main

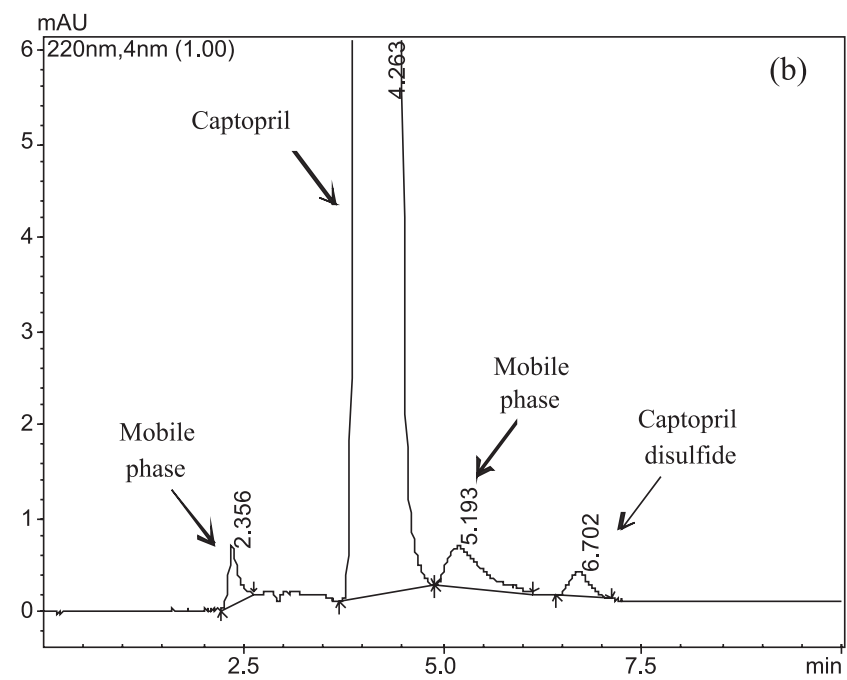

FIGURE 2 - Chromatogram of captopril USP reference standard (500 $\mu \mathrm{g} / \mathrm{g})$ (a) in full scale and (b) in enlarged view, showing peaks of captopril $\left(\mathrm{t}_{\mathrm{R}}=4.3 \mathrm{~min}\right)$ and its main impurity captopril disulfide $\left(\mathrm{t}_{\mathrm{R}}=6.7 \mathrm{~min}\right)$ present in small amount, as well as mobile phase signals. Experimental conditions: see Figure 1. 

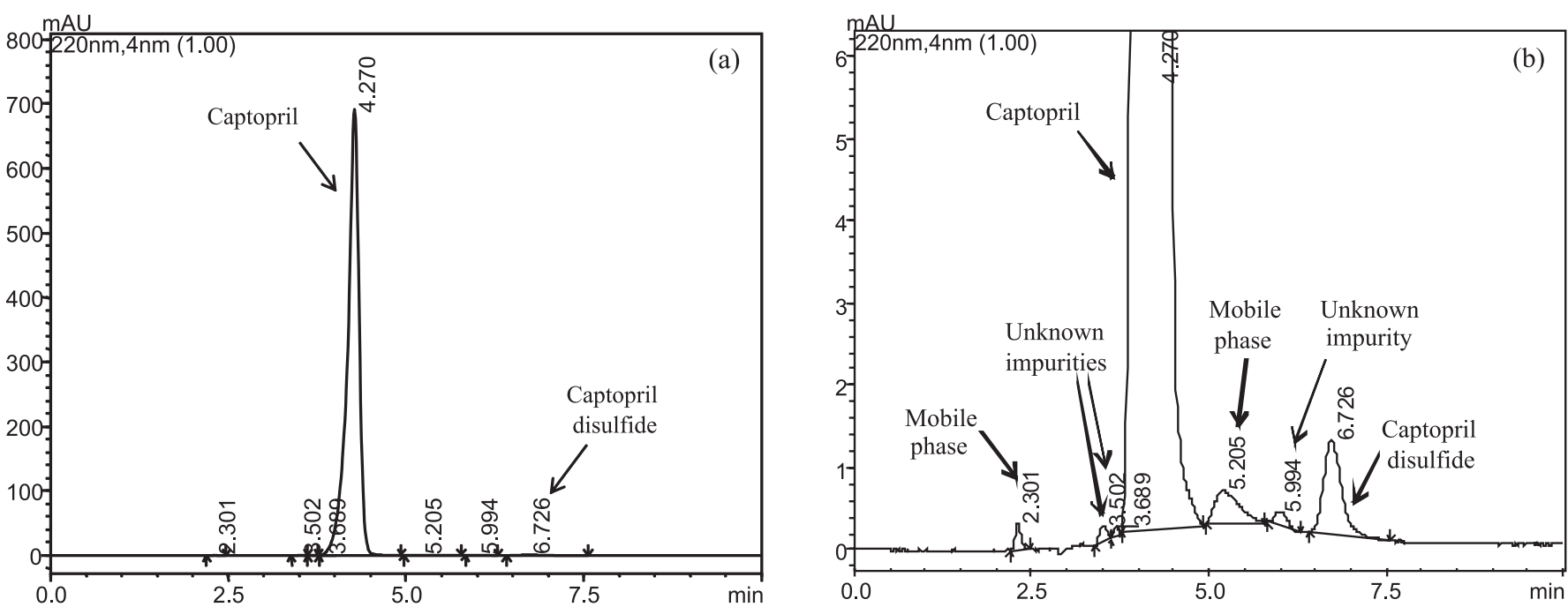

FIGURE 3 - Chromatogram of captopril candidate CRM $(500 \mu \mathrm{g} / \mathrm{g})(\mathrm{a})$ in full scale and (b) in enlarged view, showing the peaks of captopril $\left(t_{R}=4.3 \mathrm{~min}\right)$, captopril disulfide $\left(t_{R}=6.7 \mathrm{~min}\right)$, three unknown impurities $\left(\mathrm{t}_{\mathrm{R}}=3.5 \mathrm{~min}, \mathrm{t}_{\mathrm{R}}=3.7\right.$ min and $\left.\mathrm{t}_{\mathrm{R}}=6.0 \mathrm{~min}\right)$ and mobile phase signals. Experimental conditions: see Figure 1.

TABLE I - Specificity tests using captopril and captopril disulfide solutions, with evaluation of peak purity indexes, peak resolution, recoveries and behavior under stress conditions

\begin{tabular}{|c|c|c|c|c|c|c|c|c|}
\hline & \multicolumn{3}{|c|}{ Captopril disulfide } & \multicolumn{3}{|c|}{ Captopril } & \multicolumn{2}{|c|}{ Resolution } \\
\hline & $\begin{array}{c}t_{\mathrm{R}} \\
(\mathrm{min})\end{array}$ & $\begin{array}{c}\text { Assay } \\
(\%)\end{array}$ & $\begin{array}{l}\text { Peak } \\
\text { purity } \\
\text { index }\end{array}$ & $\begin{array}{c}\mathrm{t}_{\mathrm{R}} \\
(\mathrm{min})\end{array}$ & $\begin{array}{c}\text { Assay } \\
(\%)\end{array}$ & $\begin{array}{l}\text { Peak } \\
\text { purity } \\
\text { index }\end{array}$ & $\mathrm{C} / \mathrm{I}^{(4)}$ & $\mathrm{C} / \mathrm{D}^{(5)}$ \\
\hline$\overline{\text { Diluent }}$ & - & - & - & - & - & - & - & - \\
\hline Disulfide std ${ }^{(1)} 10 \mu \mathrm{g} / \mathrm{g}$ & 6.52 & $99.0^{(3)}$ & 1.000 & - & - & - & - & - \\
\hline Captopril std ${ }^{(2)} 500 \mu \mathrm{g} / \mathrm{g}$ & 6.50 & 0.07 & - & 4.21 & $100.0^{(3)}$ & 1.000 & - & 5.18 \\
\hline Captopril std $10 \mu \mathrm{g} / \mathrm{g}$ & - & - & - & 4.21 & $100.0^{(3)}$ & 1.000 & - & - \\
\hline Captopril CRM $500 \mu \mathrm{g} / \mathrm{g}$ & 6.49 & 0.23 & - & 4.21 & 98.93 & 1.000 & 1.34 & 5.01 \\
\hline Disulfide std + captopril CRM $(10+500 \mu \mathrm{g} / \mathrm{g})$ & 6.52 & 96.82 & 1.000 & 4.21 & - & 1.000 & - & - \\
\hline Disulfide std + captopril std $(10+500 \mu \mathrm{g} / \mathrm{g})$ & 6.48 & 97.65 & 1.000 & 4.21 & - & 1.000 & - & - \\
\hline \multicolumn{9}{|l|}{ Captopril CRM under stress conditions: } \\
\hline $80^{\circ} \mathrm{C}$ & - & - & 1.000 & - & - & 0.980 & - & - \\
\hline $120^{\circ} \mathrm{C}$ & - & - & 0.982 & - & - & 0.980 & - & - \\
\hline $140^{\circ} \mathrm{C}$ & - & - & 0.989 & - & - & 0.987 & - & - \\
\hline $250^{\circ} \mathrm{C}$ & - & - & 0.927 & - & - & 0.955 & - & - \\
\hline $1 \mathrm{~mol} / \mathrm{L} \mathrm{HCl}$ & - & 0.82 & 1.000 & - & 97.84 & 1.000 & - & - \\
\hline $1 \mathrm{~mol} / \mathrm{L} \mathrm{NaOH}$ & - & 0.44 & 1.000 & - & 97.27 & 1.000 & - & - \\
\hline $3 \% \mathrm{H}_{2} \mathrm{O}_{2}$ & - & 2.67 & 1.000 & - & 88.42 & 1.000 & - & - \\
\hline
\end{tabular}

(1) Captopril disulfide USP reference standard

(2) Captopril USP reference standard

(3) According to USP reference standards certificate

(4) Resolution between the peaks of captopril and the closest impurity $\left(t_{R}=3.7 \mathrm{~min}\right)$

(5) Resolution between the peaks of captopril and disulfide

impurity. When captopril (Figure 4a) is dissolved in water, it oxidizes spontaneously at its sulfhydryl group, forming the disulfide (Figure 4b) (Nishikawa et al., 2004). Additionally, the captopril molecule has an amide function and can undergo hydrolysis (Timmins, Jackson, Wang, 1982). The stability of solutions prepared for impurity analysis was therefore a critical parameter to be evaluated.

Captopril CRM solutions, prepared from three 
different flasks in triplicate, were analyzed in such a way that the intervals between two sequential injections of the same solution ( $1 / 2$ and $2 / 3)$ were, on average, 5 hours. The captopril percent peak area reduced significantly between the first and the third injections of each analyzed solution (Figure 5a), showing an increase in the percent peak areas of captopril disulfide (Figure 5b) and of unknown impurities (Figure 5c). (a)

Captopril<smiles>C[C@@H](CS)C(=O)N1CCCC1C(=O)O</smiles>

(b)

\section{Captopril disulfide}

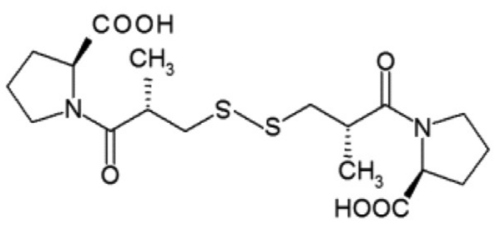

FIGURE 4 - Structural formulas of captopril (a) and of its main impurity, captopril disulfide (b).

Since the related substances test for captopril described in the Brazilian Pharmacopeia IV monograph is a limit test (maximum of $1 \%$ captopril disulfide and $2 \%$ total impurities), even if increasing amounts of disulfide and unknown impurities are formed, the raw material can still comply with this acceptance criteria. However, the characterization of the captopril CRM required an accurate determination of the organic impurities content, allowing the use of this result for the calculation of the captopril content by mass balance (eq. 1). Additionally, changes in peak areas are also a problem for method validation, especially for repeatability.

Therefore, the validation tests were performed using fresh solutions of captopril, prepared immediately before injection. This procedure significantly reduced captopril degradation as well as the corresponding formation of captopril disulfide and unknown impurities in solution.

\section{Linearity and working range}

Linearity is the ability of the analytical method to produce results directly proportional to the analyte concentration within a defined range (Inmetro, 2007).

Considering the instability of captopril in solution, the linearity tests were performed using: a) dilutions prepared from the same stock solution (higher risk of degradation) and; b) solutions prepared from different stock solutions, immediately prior to injection. Since no degradation was observed for the disulfide reference standard, its dilutions were prepared from the same stock solution.

The linearity for captopril and captopril disulfide
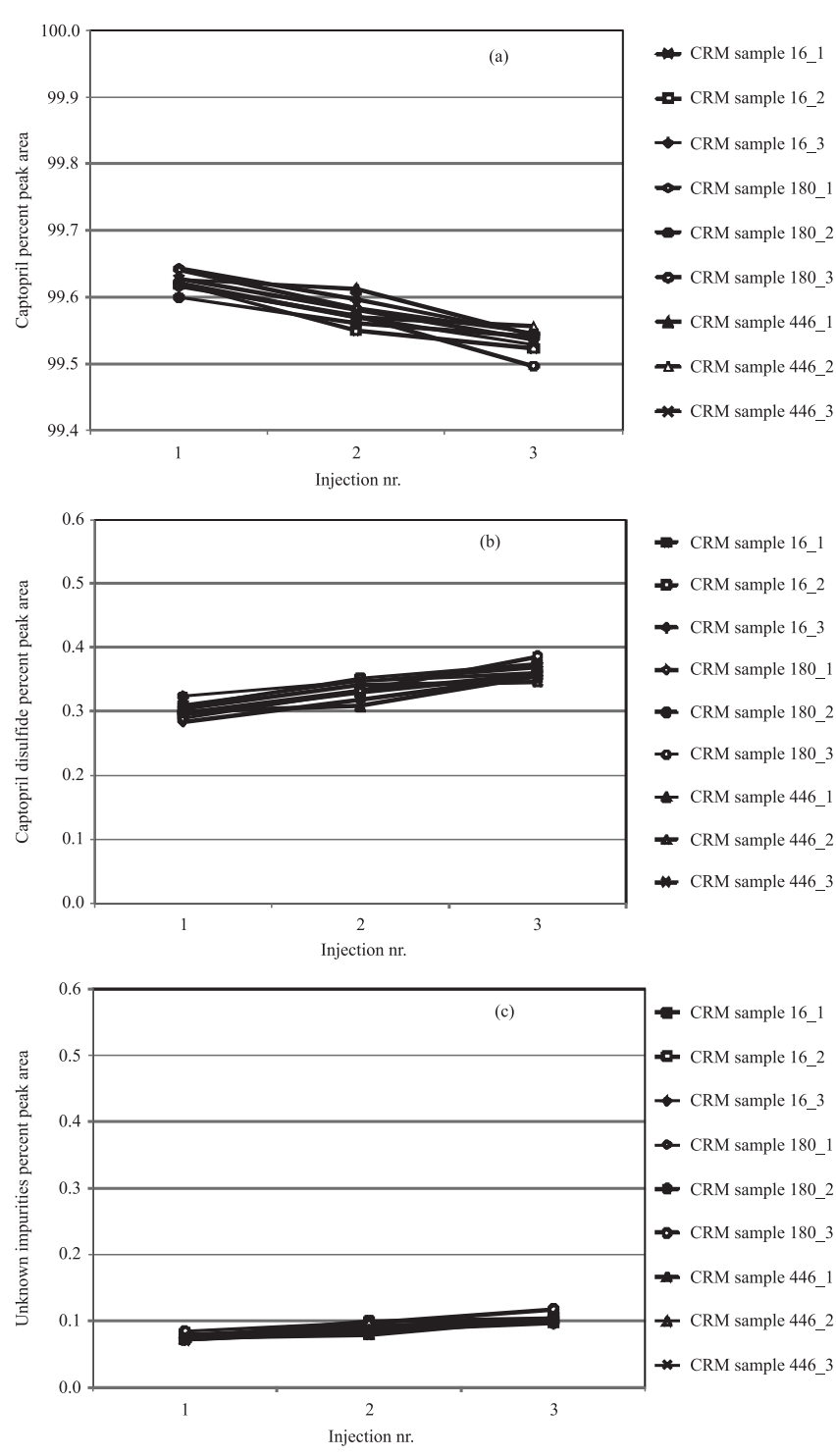

FIGURE 5 - Percent peak areas of captopril (a), captopril disulfide (b) and unknown impurities (c) for solutions containing $500 \mu \mathrm{g} / \mathrm{g}$ of captopril CRM (3 samples, solutions prepared in triplicate), which were prepared in the same set, kept at $15^{\circ} \mathrm{C}$ in the auto-sampler and injected into the HPLC system, with 5-hour intervals between injections.

was initially evaluated in the concentration range of 0.01 to $500 \mu \mathrm{g} / \mathrm{g}$. After determination of the limits of quantitation (LOQ), as described in the next section, the results below LOQ were disregarded. Additionally, the linearity was also evaluated in a narrower range between LOQ and $50 \mu \mathrm{g} / \mathrm{g}$, which corresponds to the most appropriate concentration range for organic impurities in CRM samples (the limits of captopril disulfide and total impurities in captopril samples are $1 \%$ and $2 \%$, respectively, according to the Brazilian Pharmacopeia IV, which correspond to $5 \mu \mathrm{g} / \mathrm{g}$ and $10 \mu \mathrm{g} / \mathrm{g}$ for solutions containing $500 \mu \mathrm{g} / \mathrm{g}$ of captopril). 
The statistics of the calibration curves are shown in Table II. All correlation coefficients complied with the acceptance criteria ( $\mathrm{r}>0.99$ according to Ribani et al. (2004), equivalent to $\left.r^{2}>0.98\right)$. Therefore, the linearity has been demonstrated.

\section{Limit of detection (LOD) and limit of quantitation (LOQ)}

The limit of detection (LOD) is the lowest analyte concentration that can be detected, but cannot be exactly quantified, while the limit of quantitation (LOQ) is the lowest analyte concentration that can be quantified with precision and accuracy (ICH, 1994).

The values of LOD and LOQ of captopril and capto- pril disulfide were first calculated from the linearity data. The estimated values for captopril disulfide were then confirmed by repetition of the experiments using a larger number of samples in the concentration range of 0.01 to $1.00 \mu \mathrm{g} / \mathrm{g}$ and the limits were determined according to the signal-to-noise ratio method (ICH, 2004).

The following values of LOQ and LOD were obtained: $0.35 \mu \mathrm{g} / \mathrm{g}$ and $0.11 \mu \mathrm{g} / \mathrm{g}$ for captopril disulfide; $0.25 \mu \mathrm{g} / \mathrm{g}$ and $0.08 \mu \mathrm{g} / \mathrm{g}$ for captopril, respectively (Table III). The LOQ of captopril can be used as a reference value for unknown impurities. These results were considered satisfactory, since these values are at least ten times lower than the captopril disulfide limit in captopril samples $(1 \%$ or $5 \mu \mathrm{g} / \mathrm{g}$ disulfide for $500 \mu \mathrm{g} / \mathrm{g}$ captopril solutions).

TABLE II - Linearity evaluation for captopril disulfide and captopril in two different concentration ranges (LOQ to $50 \mu \mathrm{g} / \mathrm{g}$ and LOQ to $500 \mu \mathrm{g} / \mathrm{g}$ )

\begin{tabular}{|c|c|c|c|c|c|c|}
\hline \multirow[b]{2}{*}{ Concentration range } & \multicolumn{2}{|c|}{ Captopril disulfide } & \multicolumn{2}{|c|}{ Captopril (same stock solution) } & \multicolumn{2}{|c|}{$\begin{array}{c}\text { Captopril (different stock } \\
\text { solutions prepared before } \\
\text { injection) }\end{array}$} \\
\hline & LOQ-500 $\mu \mathrm{g} / \mathrm{g}$ & $\mathrm{LOQ}-50 \mu \mathrm{g} / \mathrm{g}$ & $\mathrm{LOQ-500} \mu \mathrm{g} / \mathrm{g}$ & LOQ-50 $\mu \mathrm{g} / \mathrm{g}$ & LOQ-500 $\mu \mathrm{g} / \mathrm{g}$ & $\mathrm{LOQ}-50 \mu \mathrm{g} / \mathrm{g}$ \\
\hline Intercept $^{(1)}$ & 7666.82 & -3068.42 & 12075.10 & 1320.53 & 484.39 & -1851.37 \\
\hline Slope ${ }^{(2)}$ & 13122.98 & 13368.82 & 10472.04 & 10707.37 & 11671.12 & 11656.76 \\
\hline $\mathbf{r}^{2(3)}$ & 0.999964 & 0.999763 & 0.999934 & 0.999995 & 0.999893 & 0.999278 \\
\hline$n^{(4)}$ & 27 & 18 & 27 & 18 & 27 & 18 \\
\hline
\end{tabular}

(1) Intercept "a" of the linear regression analysis curve $y=b x+a$

(2) Slope "b" of the linear regression analysis curve $y=b x+a$

(3) Squared correlation coefficient

(4) Number of measurements

TABLE III - Determination of limit of quantitation (LOQ) and limit of detection (LOD) for captopril disulfide and captopril

\begin{tabular}{|c|c|c|c|c|c|c|}
\hline & \multicolumn{2}{|c|}{ Captopril disulfide } & \multicolumn{2}{|c|}{$\begin{array}{c}\text { Captopril (same stock } \\
\text { solution) }\end{array}$} & \multicolumn{2}{|c|}{$\begin{array}{c}\text { Captopril (different stock } \\
\text { solutions prepared before } \\
\text { injection) }\end{array}$} \\
\hline & $\mathrm{LOQ}(\mu \mathrm{g} / \mathrm{g})$ & LOD $(\mu \mathrm{g} / \mathrm{g})$ & $\operatorname{LOQ}(\mu \mathrm{g} / \mathrm{g})$ & $\operatorname{LOD}(\mu \mathrm{g} / \mathrm{g})$ & LOQ $(\mu \mathrm{g} / \mathrm{g})$ & LOD $(\mu \mathrm{g} / \mathrm{g})$ \\
\hline Estimation from linearity data & 0.3277 & 0.0983 & 0.2259 & 0.0678 & 0.2535 & 0.0760 \\
\hline \multicolumn{7}{|l|}{ Dilution series $(1.00$ - $0.01 \mu \mathrm{g} / \mathrm{g})$} \\
\hline Average - day 1 & 0.3461 & 0.1038 & & & & \\
\hline Average - day 2 & 0.3406 & 0.1022 & - & - & - & - \\
\hline Average - day 3 & 0.3736 & 0.1121 & & & & \\
\hline Average days 1-3 & 0.3534 & 0.1060 & & & & \\
\hline $\mathbf{S D}^{(1)}$ & 0.0177 & 0.0053 & - & - & - & - \\
\hline $\mathrm{CV}(\%)^{(2)}$ & 5.01 & 5.01 & & & & \\
\hline
\end{tabular}

(1) Standard deviation

(2) Coefficient of variation 


\section{Repeatability and intermediate precision}

Repeatability is the degree of compliance between the results of successive measurements under the same analysis conditions (same procedure, analyst and equipment, analysis in a short time frame), while the reproducibility evaluates the compliance between measurements under different analysis conditions (different analysts, equipment or laboratories) (Inmetro, 2007).

This reproducibility concept can be evaluated on two levels:

1. Intermediate precision: compliance between results from the same laboratory, albeit on different days and by different analysts (Anvisa, 2003).

2. Reproducibility: agreement between results from different laboratories, usually by means of interlaboratory studies (Anvisa, 2003), which is beyond the scope of this article.

Results for repeatability and intermediate precision are shown in Table IV. Repeatability was demonstrated by the small coefficients of variation $(\mathrm{CV})$ of normalized peak areas and recoveries for six repeated injections of captopril and captopril disulfide USP reference standard solutions (CV: $0.41-0.44 \%$ for captopril disulfide, $0.13-0.20 \%$ for captopril). Intermediate precision was confirmed by single-factor analysis of variance (ANOVA) (Table V) using the recoveries from Table IV (results for two different days, carried out by different analysts). The calculated $F$ values were smaller than the critical $F$ values and the acceptance criteria were therefore fulfilled.

\section{Accuracy}

Accuracy is the agreement between the result obtained and the reference value accepted as the true value. The accuracy evaluation can be performed by recovery tests, interlaboratory studies, use of reference materials (Inmetro, 2007) and comparison of results from different methods.

\section{Recovery tests}

The recovery studies were carried out using solutions of captopril disulfide USP reference standard at concentrations of $7.5,10.0$ and $12.5 \mu \mathrm{g} / \mathrm{g}(75 \%$ to $125 \%$ of the total organic impurity limit of $10 \mu \mathrm{g} / \mathrm{g})$, having $500 \mu \mathrm{g} / \mathrm{g}$ of captopril CRM or captopril USP reference standard (considered as matrixes) added or otherwise. Since these matrixes also contained small amounts of

TABLE IV - Repeatability and intermediate precision results for six replicate HPLC injections of captopril disulfide and captopril on two different days

\begin{tabular}{|c|c|c|c|c|c|c|c|c|c|c|}
\hline \multirow[b]{2}{*}{$\begin{array}{l}\text { Day- } \\
\text { injection }\end{array}$} & \multicolumn{5}{|c|}{ Captopril disulfide } & \multicolumn{5}{|c|}{ Captopril } \\
\hline & $\begin{array}{c}\text { Theoretical } \\
\text { conc. } \\
(\mu \mathrm{g} / \mathrm{g})\end{array}$ & Area & $\begin{array}{c}\text { Normalized } \\
\text { peak area } \\
(10 \mu \mathrm{g} / \mathrm{g})\end{array}$ & $\begin{array}{l}\text { Real } \\
\text { conc. } \\
(\mu \mathrm{g} / \mathrm{g})\end{array}$ & $\begin{array}{c}\text { Recovery } \\
\text { (\%) }\end{array}$ & $\begin{array}{c}\text { Theoretical } \\
\text { conc. } \\
(\mu \mathrm{g} / \mathrm{g})\end{array}$ & Area & $\begin{array}{c}\text { Normalized } \\
\text { peak area } \\
(10 \mu \mathrm{g} / \mathrm{g})\end{array}$ & $\begin{array}{l}\text { Real } \\
\text { conc. } \\
(\mu \mathrm{g} / \mathrm{g})\end{array}$ & $\begin{array}{c}\text { Recovery } \\
\text { (\%) }\end{array}$ \\
\hline $1 \_1$ & 10.97 & 143817 & 131089.21 & 10.55 & 96.19 & 10.28 & 125932 & 122452.18 & 10.76 & 104.59 \\
\hline $1 \_2$ & 10.97 & 143278 & 130597.91 & 10.51 & 95.81 & 10.28 & 126126 & 122640.82 & 10.77 & 104.75 \\
\hline $1 \_3$ & 10.97 & 142762 & 130127.58 & 10.47 & 95.45 & 10.28 & 125880 & 122401.61 & 10.75 & 104.55 \\
\hline $1 \_4$ & 10.97 & 142868 & 130224.20 & 10.48 & 95.52 & 10.28 & 125444 & 121977.66 & 10.71 & 104.19 \\
\hline $1 \_5$ & 10.97 & 142616 & 129994.50 & 10.46 & 95.35 & 10.28 & 125680 & 122207.14 & 10.73 & 104.38 \\
\hline 1_6 & 1097 & 144068 & 131318.00 & 10.57 & 96.37 & 10.28 & 126053 & 122569.83 & 10.77 & 104.69 \\
\hline$\overline{\text { Average }}$ & & & 130558.56 & & 95.78 & & & 122374.87 & & 104.53 \\
\hline CV \% ${ }^{(1)}$ & & & 0.42 & & 0.44 & & & 0.20 & & 0.20 \\
\hline 2 & 10.68 & 139523 & 130592.44 & 10.22 & 95.68 & 10.98 & 134529 & 122541.59 & 11.49 & 104.69 \\
\hline $2 \_2$ & 10.68 & 138921 & 130028.97 & 10.18 & 95.25 & 10.98 & 134376 & 122402.22 & 11.48 & 104.57 \\
\hline $2 \_3$ & 10.68 & 140125 & 131155.91 & 10.27 & 96.12 & 10.98 & 134220 & 122260.12 & 11.47 & 104.45 \\
\hline $2 \_4$ & 10.68 & 139315 & 130397.75 & 10.21 & 95.53 & 10.98 & 134628 & 122631.77 & 11.50 & 104.77 \\
\hline $2 \_5$ & 10.68 & 139047 & 130146.91 & 10.19 & 95.34 & 10.98 & 134682 & 122680.95 & 11.51 & 104.81 \\
\hline 266 & 10.68 & 140326 & 131344.04 & 10.28 & 96.26 & 10.98 & 134430 & 122451.41 & 11.48 & 104.61 \\
\hline Average & & & 130611.00 & & 95.70 & & & 122494.68 & & 104.65 \\
\hline CV \% ${ }^{(1)}$ & & & 0.41 & & 0.43 & & & 0.13 & & 0.13 \\
\hline
\end{tabular}

(1) Coefficient of variation 
TABLE V - Single-factor analysis of variance (ANOVA) of recoveries (Table IV) for intermediate precision evaluation

\begin{tabular}{|c|c|c|c|c|c|c|c|c|c|c|c|c|}
\hline \multirow{2}{*}{$\begin{array}{l}\text { Source of } \\
\text { variation }\end{array}$} & \multicolumn{6}{|c|}{ Captopril disulfide } & \multicolumn{6}{|c|}{ Captopril } \\
\hline & $\mathrm{SS}^{(1)}$ & $\mathrm{df}^{(2)}$ & $\mathrm{MS}^{(3)}$ & $\mathrm{F}^{(4)}$ & p-value ${ }^{(5)}$ & $\mathrm{F}_{\text {crit }}{ }^{(6)}$ & SS & $\mathrm{df}$ & MS & $\mathrm{F}$ & $\mathrm{p}$-value & $\mathrm{F}_{\text {crit }}$ \\
\hline $\begin{array}{l}\text { Between } \\
\text { groups }\end{array}$ & 0.0207 & 1 & 0.0207 & 0.1203 & 0.7359 & 4.9646 & 0.0455 & 1 & 0.0455 & 1.4668 & 0.2537 & 4.9646 \\
\hline $\begin{array}{l}\text { Within } \\
\text { groups }\end{array}$ & 1.7199 & 10 & 0.1720 & & & & 0.3101 & 10 & 0.0310 & & & \\
\hline Total & 1.7405 & 11 & & & & & 0.3556 & 11 & & & & \\
\hline
\end{tabular}

(1) Sum of squares

(2) Degrees of freedom

(3) Mean square, estimated by the equation MS $=\mathrm{SS} / \mathrm{df}$

(4) Calculated $\mathrm{F}$ value according to the equation $\mathrm{F}=\mathrm{MS}_{\text {between }} / \mathrm{MS}_{\text {within }}$

(5) If $\mathrm{p}$-value $>0.05$ (and $\mathrm{F}<\mathrm{F}_{\text {crit }}$ ), there is no significant difference between the two data groups

(6) Critical value from the $\mathrm{F}$ distribution, estimated by the equation $\mathrm{F}_{\text {crit }}=\operatorname{INVF}(0.05 ; 1 ; \mathrm{df}($ residual $))$

captopril disulfide, they were individually analyzed, so that their captopril disulfide peak areas could be subtracted before recovery calculation.

The results obtained can be seen in Table VI. The recovery of captopril disulfide in the absence of matrixes was in the $93.1 \%$ to $97.4 \%$ range, while its recovery in the presence of matrixes was between $94.0 \%$ and $98.6 \%$. These two ranges are comparable and both comply with the established acceptance criteria (recoveries between 90.0 and $110.0 \%$ ), thus confirming the method accuracy.

\section{Comparison between different methods}

The use of different analytical methods is recommended to determine the purity of reference materials, in order to obtain metrologically accepted results (Duewer et al., 2004). For characterization of a candidate certified reference material in a single laboratory, two possible approaches are presented by the ISO Guide 35:2006: 1) use of one primary method, which is a method that does not rely on the use of a "measurement standard for a quantity of the same kind" (JCGM, 2008), and; 2) combination of two independent secondary methods. The other procedures described by the cited ISO Guide require a network of laboratories.

The captopril contents determined by the following methods have been compared:

1. Assay of captopril by oxidation-reduction titration (iodometry) according to the assay method in the Brazilian Pharmacopeia IV monograph;

2. Differential scanning calorimetry (DSC) according to Moreira et al. (2010). This thermal method determines the "degree of deviation from the expected behavior of an ideal $100 \%$ pure sample caused by the presence of impurities that are more soluble in the material's liquid phase than in its solid phase" (Duewer et al., 2004);

3. Mass balance according to eq. 1, after determination of impurities by RP-HPLC-DAD (organic impurities), residue on ignition (inorganic impurities) and loss on drying (volatiles).

As can be seen in Table VII, the titration results for the captopril CRM were greater than 100\% (100.04\%, CV $0.32 \%, \mathrm{n}=24$, analysis in triplicate) and therefore this technique, which is a primary method (Duewer et al., 2004; Gorog, 2005), was not indicated for characterization and certification of the captopril reference material. These results may be explained by the variability of titrimetric methods (Rodomonte, Montinaro, Bartolomei, 2006) and also by the non-specificity of this technique (Gorog, 2005), since organic impurities usually contain a moiety of similar reactivity to that of the analyte (Duewer et al., 2004; Gorog, 2005).

The DSC can also be considered a primary method, even if in practice empirical corrections may be necessary (Duewer et al., 2004). The captopril analysis by DSC demonstrated that the purity of analytes with a known impurity profile, such as captopril CRM, can be determined equivalently by DSC and HPLC (Moreira et al., 2010). The captopril content by DSC was $99.65 \pm 0.023 \% \mathrm{~mol} / \mathrm{mol}$, while the result obtained by mass balance was $99.565 \pm$ $0.093 \% \mathrm{w} / \mathrm{w}$ (Table VII), thus indicating the accuracy of both methods.

\section{Robustness}

A method is considered robust when it is virtually insensitive to small variations (Inmetro, 2007). The ro- 
TABLE VI - Recoveries of captopril disulfide in the presence of captopril matrixes for accuracy evaluation

\begin{tabular}{|c|c|c|c|c|c|c|c|}
\hline & $\begin{array}{l}\text { Theoretical } \\
\text { disulfide } \\
\text { conc. }(\mu \mathrm{g} / \mathrm{g})\end{array}$ & $\begin{array}{l}\text { Disulfide } \\
\text { peak area }\end{array}$ & $\begin{array}{c}\text { Added } \\
\text { matrix }(\mu \mathrm{g} / \mathrm{g}) \\
\end{array}$ & $\begin{array}{c}\text { Disulfide } \\
\text { peak area in } \\
\text { matrix } \\
\end{array}$ & $\begin{array}{c}\text { Corrected } \\
\text { disulfide } \\
\text { peak area }{ }^{(1)}\end{array}$ & $\begin{array}{c}\text { Real } \\
\text { disulfide } \\
\text { conc. }(\mu \mathrm{g} / \mathrm{g})\end{array}$ & $\begin{array}{c}\text { Recovery } \\
(\%)\end{array}$ \\
\hline \multirow{9}{*}{$\begin{array}{l}\text { Captopril disulfide USP } \\
\text { reference standard }\end{array}$} & 8.10 & 104587 & - & - & 104587 & 7.54 & 93.09 \\
\hline & 8.10 & 104562 & - & - & 104562 & 7.54 & 93.07 \\
\hline & 8.10 & 105421 & - & - & 105421 & 7.60 & 93.89 \\
\hline & 11.13 & 145828 & - & - & 145828 & 10.71 & 96.19 \\
\hline & 11.13 & 145806 & - & - & 145806 & 10.71 & 96.17 \\
\hline & 11.13 & 145921 & - & - & 145921 & 10.71 & 96.25 \\
\hline & 13.95 & 183387 & - & - & 183387 & 13.60 & 97.45 \\
\hline & 13.95 & 182810 & - & - & 182810 & 13.55 & 97.13 \\
\hline & 13.95 & 182650 & - & - & 182650 & 13.54 & 97.04 \\
\hline \multirow{9}{*}{$\begin{array}{l}\text { Captopril disulfide USP } \\
\text { reference standard plus } \\
\text { captopril CRM }\end{array}$} & 8.33 & 125845 & 575.93 & 17456 & 108389 & 7.83 & 93.95 \\
\hline & 8.33 & 126115 & 575.93 & 17456 & 108659 & 7.85 & 94.20 \\
\hline & 8.33 & 126738 & 575.93 & 17456 & 109282 & 7.90 & 94.77 \\
\hline & 11.09 & 162479 & 548.81 & 16634 & 145845 & 10.71 & 96.59 \\
\hline & 11.09 & 162787 & 548.81 & 16634 & 146153 & 10.73 & 96.80 \\
\hline & 11.09 & 163172 & 548.81 & 16634 & 146538 & 10.76 & 97.07 \\
\hline & 13.90 & 199924 & 533.54 & 16171 & 183753 & 13.62 & 98.03 \\
\hline & 13.90 & 199682 & 533.54 & 16171 & 183511 & 13.60 & 97.90 \\
\hline & 13.90 & 201035 & 533.54 & 16171 & 184864 & 13.71 & 98.64 \\
\hline \multirow{3}{*}{$\begin{array}{l}\text { Disulfide USP reference } \\
\text { standard plus captopril USP } \\
\text { reference standard }\end{array}$} & 11.16 & 152788 & 562.19 & 5168 & 147620 & 10.85 & 97.20 \\
\hline & 11.16 & 153364 & 562.19 & 5168 & 148196 & 10.89 & 97.59 \\
\hline & 11.16 & 154194 & 562.19 & 5168 & 149026 & 10.95 & 98.17 \\
\hline
\end{tabular}

(1) Disulfide peak area after subtraction of disulfide peak area in the matrix

TABLE VII - Comparison of captopril contents determined by different methods for accuracy evaluation

\begin{tabular}{ccc}
\hline Mass balance $^{(1)}$ & Titration & DSC \\
\hline $99.565 \% \pm 0.093 \% \%^{(2)}$ & $100.04 \% \pm 0.32 \%^{(3)}$ & $99.650 \% \pm 0.023 \% \mathrm{~mol}^{(3)} / \mathrm{mol}^{(3)}$ \\
\hline
\end{tabular}

(1) According to eq. 1, using the following methods: RP-HPLC-DAD (organic impurities), residue on ignition (inorganic impurities) and loss on drying (volatiles). (2) Expanded measurement uncertainty (U). (3) Standard deviation

bustness test was planned according to Youden \& Steiner (Inmetro, 2007) and the parameters evaluated were:

- Mobile phase flow-rate $(1 \mathrm{~mL} / \mathrm{min})$ : “A” $(1.1 \mathrm{ml} /$ $\min )$, "a" (0.9 $\mathrm{mL} / \mathrm{min})$;

- Detection wavelength (220 nm): "B" (225 nm), "b" (215 nm);

- $\quad o$-Phosphoric acid concentration in the aqueous phase (mobile phase) $(0.11 \% \mathrm{v} / \mathrm{v})$ : “C” $(0.12 \% \mathrm{v} / \mathrm{v})$, "c" $(0.10 \% \mathrm{v} / \mathrm{v})$;

- Methanol concentration in the organic phase (mobile phase) (55\% v/v): "D" (58\% v/v), “d” (52\% v/v).

The captopril contents in the tested CRM solutions $(10 \mu \mathrm{g} / \mathrm{g})(\mathrm{s}, \mathrm{t}, \mathrm{u}, \mathrm{v}, \mathrm{w}, \mathrm{x}, \mathrm{y}, \mathrm{z})$ under eight different experimental conditions are shown in Table VIII.

The factors A, a, B, b, C, c, D and d were calculated by equations 2 to 9 (Inmetro, 2007).

$$
\begin{gathered}
\mathrm{A}=(\mathrm{s}+\mathrm{t}+\mathrm{u}+\mathrm{v}) / 4 \\
\mathrm{~B}=(\mathrm{s}+\mathrm{t}+\mathrm{w}+\mathrm{x}) / 4 \\
\mathrm{C}=(\mathrm{s}+\mathrm{u}+\mathrm{w}+\mathrm{y}) / 4 \\
\mathrm{D}=(\mathrm{s}+\mathrm{t}+\mathrm{y}+\mathrm{z}) / 4 \\
\mathrm{a}=(\mathrm{w}+\mathrm{x}+\mathrm{y}+\mathrm{z}) / 4 \\
\mathrm{~b}=(\mathrm{u}+\mathrm{v}+\mathrm{y}+\mathrm{z}) / 4 \\
\mathrm{c}=(\mathrm{t}+\mathrm{v}+\mathrm{x}+\mathrm{z}) / 4 \\
\mathrm{~d}=(\mathrm{u}+\mathrm{v}+\mathrm{w}+\mathrm{x}) / 4
\end{gathered}
$$

The results obtained are shown in Table IX and complied with the acceptance criteria (coefficient of variation of all results less than 5\%; differences between $\mathrm{A}$ and a, B and $b$, and so on, no greater than $3 \%$ ). Therefore, the method was considered robust for the evaluated parameters (detection wavelength, mobile phase flow-rate and mobile phase composition). 
TABLE VIII - Captopril contents ( $\mathrm{s}$ to z) determined under eight different experimental conditions for method robustness evaluation

\begin{tabular}{|c|c|c|c|c|c|c|c|c|}
\hline & 1 & 2 & 3 & 4 & 5 & 6 & 7 & 8 \\
\hline $\mathrm{A} / \mathrm{a}$ & $1.1 \mathrm{~mL} / \mathrm{min}$ & $1.1 \mathrm{~mL} / \mathrm{min}$ & $1.1 \mathrm{~mL} / \mathrm{min}$ & $1.1 \mathrm{~mL} / \mathrm{min}$ & $0.9 \mathrm{~mL} / \mathrm{min}$ & $0.9 \mathrm{~mL} / \mathrm{min}$ & $0.9 \mathrm{~mL} / \mathrm{min}$ & $0.9 \mathrm{~mL} / \mathrm{min}$ \\
\hline $\mathrm{B} / \mathrm{b}$ & $225 \mathrm{~nm}$ & $225 \mathrm{~nm}$ & $215 \mathrm{~nm}$ & $215 \mathrm{~nm}$ & $225 \mathrm{~nm}$ & $225 \mathrm{~nm}$ & $215 \mathrm{~nm}$ & $215 \mathrm{~nm}$ \\
\hline $\mathrm{D} / \mathrm{d}$ & $58 \% \mathrm{MeOH}$ & $58 \% \mathrm{MeOH}$ & $52 \% \mathrm{MeOH}$ & $52 \% \mathrm{MeOH}$ & $52 \% \mathrm{MeOH}$ & $52 \% \mathrm{MeOH}$ & $58 \% \mathrm{MeOH}$ & $58 \% \mathrm{MeOH}$ \\
\hline $\begin{array}{l}\text { Captopril } \\
\text { content }\end{array}$ & $99.76 \%$ & $104.08 \%$ & $106.56 \%$ & $98.74 \%$ & $106.79 \%$ & $98.42 \%$ & $99.97 \%$ & $104.53 \%$ \\
\hline
\end{tabular}

TABLE IX - Youden and Steiner parameters for method robustness

\begin{tabular}{|c|c|c|c|}
\hline \multicolumn{2}{|c|}{ Captopril contents ${ }^{(1)}$} & \multirow{2}{*}{$\frac{\text { Differences }}{\mathbf{A}-\mathbf{a}(\%)}$} & \multirow{2}{*}{$\frac{\text { Robustnes }}{\text { Robust }}$} \\
\hline$A(\%)$ & a (\%) & & \\
\hline 102.28 & 102.43 & -0.15 & \\
\hline B (\%) & b $(\%)$ & $\mathbf{B}-\mathbf{b}(\%)$ & Robust \\
\hline 102.26 & 102.45 & -0.19 & \\
\hline $\mathrm{C}(\%)$ & c $(\%)$ & $\mathrm{C}-\mathrm{c}(\%)$ & Robust \\
\hline 103.27 & 101.44 & 1.83 & \\
\hline D (\%) & d $(\%)$ & $D-d(\%)$ & Robust \\
\hline 102.09 & 102.63 & -0.54 & \\
\hline Average (\%) & 102.36 & & \\
\hline $\mathbf{S D}^{(2)}$ & 0.51 & & \\
\hline $\mathrm{CV}(\%)^{(3)}$ & 0.50 & & \\
\hline
\end{tabular}

(1) According to eq. 2 to eq. 9

(2) Standard deviation

(3) Coefficient of variation

\section{CONCLUSIONS}

The results obtained in this study complied with the proposed acceptance criteria, and the RP-HPLC-DAD method for determination of related substances of captopril was considered validated and accurate for quantification of organic impurities, allowing the use of the mass balance approach for calculation of the captopril content in the captopril candidate CRM.

The observed instability of captopril in solution was resolved by using fresh captopril solutions, prepared immediately before injection into the HPLC system.

\section{ACKNOWLEDGEMENTS}

We are grateful for the support provided by "Cristália Produtos Químicos e Farmacêuticos Ltda" and "Medley S. A. Indústria Farmacêutica”.

\section{REFERENCES}

ASSOCIAÇÃO BRASILEIRA DE NORMAS TÉCNICAS/ INSTITUTO NACIONAL DE METROLOGIA, NORMALIZAÇÃO E QUALIDADE INDUSTRIAL. Guia para a expressão da incerteza de medição. 3.ed. (revisada). Rio de Janeiro: ABNT/Inmetro, 2003. 120 p.

ASSOCIAÇÃO BRASILEIRA DE NORMAS TÉCNICAS. ABNT NBR ISO/IEC 17025:2005. Requisitos gerais para competência de laboratórios de ensaio e calibração. Rio de Janeiro: ABNT, 2005. $31 \mathrm{p}$.

AGÊNCIA NACIONAL DE VIGILÂNCIA SANITÁRIA. Resolução-RE No 899 de 29 de maio de 2003. Guia para validação de métodos analíticos e bioanalíticos. Diário Oficial da União, Brasília, DF, 02 de junho de 2003. p.5659. Available at: $<$ http://www.in.gov.br/imprensa/visualiza/ index.jsp?jornal $=1 \&$ pagina $=56 \&$ data $=02 / 06 / 2003>$. Accessed on: 17 may 2010.

DUEWER, D.L.; PARRIS, R.M.; WHITE, E.V.; MAY, W.E.; ELBAUM, H. An approach to the metrologically sound traceable assessment of the chemical purity of organic reference materials. National Institute of Standards and Technology special publication 1012. Gaithersburg: National Institute of Standards and Technology (NIST), 2004. 53 p.

FARMACOPEIA BRASILEIRA. 4.ed. São Paulo: Atheneu, 2002. pt.2. p.181. (captopril)

GOROG, S. The sacred cow: the questionable role of assay methods in characterizing the quality of bulk pharmaceuticals. J. Pharm. Biomed. Anal., v.36, n.5, p.931937, 2005.

HOFER, J.D.; OLSEN, B. A.; RICKARD, E. C. Is HPLC assay for drug substance a useful quality control attribute? $J$. Pharm. Biomed. Anal., v.44, n.4, p.906-913, 2007. 
INSTITUTO NACIONAL DE METROLOGIA, NORMALIZAÇÃO E QUALIDADE INDUSTRIAL. DOQ-CGCRE-008. Orientação sobre a validação de métodos de ensaios químicos. rev. 02. Rio de Janeiro, 2007. 24 p. Available at: <http://www.inmetro.gov.br/ Sidoq/Arquivos/CGCRE/DOQ/DOQ-CGCRE-8_02.pdf.>. Accessed on: 01 jul. 2009.

\section{INTERNATIONAL CONFERENCE ON HARMONISATION} OF TECHNICAL REQUIREMENTS FOR REGISTRATION OF PHARMACEUTICALS FOR HUMAN USE (ICH). ICH harmonised tripartite guideline. Validation of Analytical Procedures: text and methodology. Q2(R1). Current Step 4 version. Parent Guideline dated 27 October 1994. Complementary Guideline on Methodology dated 6 November 1996 incorporated in November 2005. Available at: $<$ http://www.ich.org/LOB/media/MEDIA417. pdf.>. Accessed on: 01 jul. 2009.

I N T E R N ATIONAL OR G A I Z A T I ON F O R STANDARDIZATION. ISO Guide 34. General requirements for the competence of reference material producers. Geneve, 2009. 34 p.

I N T E R N A T I O N A L O R G A N I Z A T I O N F O R STANDARDIZATION. ISO Guide 35. Reference materials - general and statistical principles for certification. Geneve, 2006. 64 p.

\section{JOINT COMMITTEE FOR GUIDES IN METROLOGY} (JCGM). International vocabulary of metrology: basic and general concepts and associated terms (VIM). JCGM 200:2008. 3.ed. Sèvres (France): BIPM, 2008. 90 p. Available at: <http://www.bipm.org/utils/common/ documents/jcgm/JCGM_200_2008.pdf.>. Accessed on: 26 jun. 2010.

\section{LABORATORY OF THE GOVERNMENT CHEMIST (LGC)} STANDARDS. Pharmaceutical reference substances and impurities 2010 / 2011. Teddington, 2010. 421 p. Available at: <http://lgcstandards.com/media/559600807.pdf.>. Accessed on: 29 sep. 2010.

MOREIRA, G.F.; BALBO, A.; ACHETE, C.A.; BARIN, J.S.; WOLLINGER, W., NOGUEIRA, R.; BITTENCOURT, C.F.; RODRIGUES, J. M. Aplicação da calorimetria exploratória diferencial (DSC) para determinação de pureza de fármacos. $P \& P$, v.11, n.1, p.22-29, 2010.
NISHIKAWA, T.; ABE, R.; SUDO, Y.; YAMADA, A.; TAHARA, K. HPLC profile of captopril disulfide that undergoes reversible cis-trans conversion among three isomers. Anal. Sci., v.20, n.10, p.1395-1398, 2004.

NOGUEIRA, R.; REGO, E.C.P.; SOUSA, M.V.B.; WOLLINGER, W.; SILVA, T.E.; MOREIRA, G.F.; BARIN, J.S.; LAPORTA, L.V.; MESKO, M.F.; BITTENCOURT, C.F.; CAIXEIRO, J.M.R.; CUNHA, V.S. Development studies of captopril certified reference material. Braz. J. Pharm. Sci., v.47, n.2, p.339-350, 2011.

RIBANI, M.; BOTTOLi, C.B.G.; COLlins, C.H.; JARDIM, C.S.F.; MELO, L.F.C. Validação em métodos cromatográficos e eletroforéticos. Quim. Nova, v.27, n.5, p.771-780, 2004.

RODOMONTE, A.L.; MONTINARO, A.; BARTOLOMEI, $\mathrm{M}$. Uncertainty evaluation in the chloroquine phosphate potentiometric titration: application of three different approaches. J. Pharm. Biom. Anal., v.42, n.1, p.56-63, 2006.

STULZER, H.K.; TAGLIARI, M.P.; KUMINEK, G.; OLIVEIRA, P.R.; BERTOL, C.D.; SILVA, M.A.S. Development and validation of stability indicating LC method for quantify captopril in tablets of controlled release. Chromatographia, v.69, suppl.2, p.S123-S128, 2009.

THE UNITED STATES PHARMACOPEIA. USP 32 / NF 27. Rockville: The United States Pharmacopeial Convention, 2009. p.236.

THE UNITED STATES PHARMACOPEIAL CONVENTION. Available at: <http://www.usp.org $>$. Accessed on: 21 apr. 2010.

TIMMINS, P.; JACKSON, I.M.; WANG, Y.J. Factor affecting captopril stability in aqueous solution. Int. J. Pharm., v.11, n.4, p.329-336, 1982.

WILLIAMS, R.L.; PROJECT TEAM 4. Official USP reference standards: metrology concepts, overview, and scientific issues and opportunities. J. Pharm. Biomed. Anal., v.40, n.1, p.3-15, 2006.

Received for publication on $14^{\text {th }}$ May 2010 Accepted for publication on $15^{\text {th }}$ February 2011 